\title{
Mortality and morbidity caused by measles in children with malignant disease attending four major treatment centres: a retrospective review
}

\author{
MAUREEN M GRAY, IAN M HANN, SHARON GLASS, OSBORN B EDEN, \\ PAT MORRIS JONES, RICHARD F STEVENS
}

\begin{abstract}
Measles is a major cause of mortality and morbidity in children receiving treatment for leukaemia. A review was made of all the documented cases of measles in children in first remission from acute lymphoblastic leukaemia at four major treatment centres in 1974-84. Over the 11 years reviewed 1043 children with acute lymphoblastic leukaemia were referred to these centres. Fifty one $(4.9 \%)$ died while in first remission and $15(29.4 \%)$ of these deaths were due to measles or its complications: 12 cases of pneumonia, 10 of them fatal; and six cases of encephalitis, five of them fatal and the sixth child left severely handicapped. These children would have had at least a $50 \%$ chance of long term survival.
\end{abstract}

The severity of measles in the immunocompromised patient reinforces the need to improve the poor uptake of measles immunisation in Britain.

\section{Introduction}

There are now effective treatment regimens for most childhood malignancies with disease free survival over five years being about $50 \%$. The commonest childhood malignancy is acute lymphoblastic leukaemia, which now has at least a $60 \%$ five year disease free survival. ${ }^{1}$ Unfortunately the treatment causes major immunosuppression, leaving the patient susceptible to infection during treatment and for several months thereafter, especially from viruses, Pneumocystis carinii, and to a lesser extent bacteria. The use of prophylactic co-trimoxazole has prevented $P$ carinii pneumonitis very effectively. ${ }^{2}$ Varicella zoster immunoglobulin is effective in preventing varicella zoster, and acyclovir is useful in treating varicella zoster and herpes simplex. ${ }^{3}$ The remaining major cause of mortality and morbidity from infection during immunosuppression is the measles virus.

If immunocompromised children contract measles they almost invariably have severe complications but often have few or none of the usual clinical features. In particular the rash may be mild and atypical or absent. The complications in the immunosuppressed take two main forms: the first and more common is a severe pneumonitis occurring at the time of the measles infection but

Department of Haematology, Royal Hospital for Sick Children, Glasgow G3 8SJ

MAUREEN M GRAY, MB, CHB, clinical assistant

IAN M HANN, MRCP, MRCPATH, consultant haematologist

Department of Paediatric Haematology, Royal Hospital for Sick Children, Edinburgh EH9 1LF

SHARON GLASS, MB, MRCP, clinical assistant

OSBORN B EDEN, MB, FRCPED, consultant haematologist

Department of Paediatric Oncology, Royal Manchester Children's Hospital, Manchester M27 1HA

PAT MORRIS JONES, MB, FRCP, reader in child health (paediatric oncology) RICHARD F STEVENS, MRCP, MRCPATH, consultant haematologist

Correspondence to: Dr Gray. distinct from the secondary bacterial pneumonias seen in the nonimmunosuppressed. The second complication is a unique type of delayed encephalitis, also distinct from acute measles encephalomyelitis and subacute sclerosing panencephalitis seen in the nonimmunosuppressed. Both of these leukaemia related complications are usually fatal, although there are occasional long term survivors who suffer severe neurological handicap.

The immunosuppression caused by both the leukaemia itself and its treatment may result in the suppression of any immunity previously acquired to measles from either past infection or immunisation. In the past the administration of routine active immunisation has resulted in immunosuppressed children developing severe measles infection. ${ }^{4}$ Some Japanese workers have given a live attenuated measles vaccine to children with leukaemia and shown that it apparently produces a good antibody response with minimal side effects, ${ }^{5}$ but the experience in Britain of giving normal human immunoglobulin has shown that it does not always confer enough passive immunity to prevent measles infection. ${ }^{6}$ Further work is therefore required to find effective prophylaxis or treatment for this serious infection.

\section{Patients and methods}

The case notes of patients in first remission from acute lymphoblastic leukaemia known to have had measles infections during 1974-84 at four major paediatric treatment centres were extracted and the cases tabulated. The four centres were: the Royal Hospital for Sick Children, Glasgow; Royal Hospital for Sick Children, Edinburgh; Royal Manchester Children's Hospital; and Hospital for Sick Children, Great Ormond Street, London. In addition, the case notes of all the children treated in the haematology departments of the Royal Hospitals for Sick Children in Glasgow and Edinburgh in 1978-84 were reviewed. The policy adopted had been to give intramuscular injections of normal human immunoglobulin within $\mathbf{4 8}$ hours of any contact with measles during the "at risk" period-that is, during treatment and for six months afterwards. Table I shows the number of injections given to patients attending these two centres and the total number at risk. This was an attempt to assess the extent of the problem population throughout the period of the study.

TABLE I-Numbers of injections given to at risk patients attending the Royal Hospitals for Sick Children in Glasgow and Edinburgh during 1978-84

\begin{tabular}{cccc}
\hline Year & $\begin{array}{c}\text { No of patients } \\
\text { at risk }\end{array}$ & $\begin{array}{c}\text { No of injections } \\
(\%)\end{array}$ & $\begin{array}{c}\text { No of cases } \\
\text { of measles }\end{array}$ \\
\hline 1978 & 92 & $14(15 \cdot 2)$ & 0 \\
1979 & 93 & $28(30 \cdot 1)$ & 0 \\
1980 & 99 & $10(10 \cdot 1)$ & 0 \\
1981 & 82 & $14(17 \cdot 1)$ & 0 \\
1982 & 98 & $30(30 \cdot 6)$ & 2 \\
1983 & 116 & $14(12 \cdot 1)$ & 1 \\
1984 & 101 & $15(14 \cdot 9)$ & 2 \\
\hline
\end{tabular}

\section{Results}

There were $18(1.7 \%)$ cases of measles found in this series of 1043 patients. referred to the four centres for treatment of acute lymphoblastic leukaemia; 15 of these were fatal $(83 \cdot 3 \%)$. No definite case of uncomplicated measles was found, although one child had a typical measles rash with a mild chest 
infection that responded to erythromycin; he recovered but the illness was never virologically proved to be measles. There were also several other cases of fatal viral pneumonia in which the causative organism was suspected, but never proved, to be measles. Of the 18 children, only one had been immunised against measles, although all were over the age recommended for immunisation when the leukaemia occurred, and two patients had had clinical measles previously. This previous immunity to measles had no protective effect as these three children died and the three survivors had not been immunised or previously infected.

It is difficult to assess the incubation period in these patients as there was no history of contact with measles in nine of them. In the other nine the possible incubation periods varied from a few days to two months. Of those with known contacts, five were given immunoglobulin, and of these five, three had incubation times within accepted limits $(11,14$, and 18 days) and the other two had abnormal times (three days and six weeks). In another case a sibling had had measles two months before the patient developed measles complicated by pneumonia, but the patient had not been given immunoglobulin. Thus in this series there was no particular pattern of effect of the immunoglobulin on incubation times.

During 1978-84 between a tenth and a third of the population at risk at the Royal Hospitals for Sick Children in Glasgow and Edinburgh were given normal human immunoglobulin in each of the years studied; it was seldom used before 1978. This was probably an underestimate of the number of injections given because of the difficulty encountered in reviewing all the cases retrospectively and there was no way of assessing how many at risk patients were exposed to measles and did not receive immunoglobulin or proceeded to have measles infection.

Five of the cases of measles complications (two of pneumonia and three of encephalitis) occurred at the Royal Hospitals for Sick Children in Glasgow and Edinburgh; only the child with fatal pneumonia was given immunoglobulin. The measles infection itself was usually atypical or subclinical and only one patient had a typical rash preceded by Koplik's spots. Ten children had rashes that were not typical of measles but were probably associated with the measles infection. The descriptions of the rashes were varied and included "transient erythematous," "macular," and "maculopapular," but all were mild and the distribution also varied. Only one child with an atypical rash also had Koplik's spots, and six patients had some or all of the symptoms associated with the prodromal period in non-immunocompromised patients-that is, fever, upper respiratory tract infection, and anorexia-and two patients had no clinical symptoms at all.

\section{ENCEPHALITIS}

Table II shows the details of the six cases of encephalitis. There was a definite history of contact in only three, and only one patient was given immunoglobulin. In these three patients the delay between the known contact and the onset of symptoms was "a few weeks," four months, and seven months. In the other three patients there was a history of atypical rash, which was taken retrospectively to have been possible measles infection, and the time lapse until the onset of symptoms of encephalitis was 14 weeks, 18 weeks, and seven months.

In four of the six patients the encephalitis consisted of severe generalised convulsions that were poorly controlled by maximal doses of anticonvulsants; one of these patients also had a left hemiparesis. In all four there was progressive cerebral hypoxia despite ventilation with high concentrations of oxygen; this eventually led to cardiac arrest and death, although two children remained deeply comatose on ventilators for three months before death

Two patients differed in having more focal signs, and one of them (case 5 ) had only three short focal seizures but developed cortical blindness and a reduced conscious level. He was treated for 19 days with interferon, given both intramuscularly and intrathecally; this may have halted deterioration of his encephalopathy. Three weeks after interferon treatment was stopped his bone marrow showed leukaemic infiltration so no further treatment was given and he died 10 days later. The other child (case 6 ) was the only survivor among the children with encephalitis and she was left severely handicapped. She had a left hemiparesis and right sided convulsions and was treated with acyclovir for 10 days. She developed spastic rigidity of all four limbs, equinus deformity of both feet, left facial weakness, and severe scoliosis and needed a spinal support to sit. She was generally unresponsive to her surroundings and required anticonvulsant treatment as well as frequent physiotherapy to prevent chest infections. She was also doubly incontinent and required residential care. In the three and a half years after her chemotherapy was discontinued, because of the encephalitis, there was no sign of relapse of her leukaemia.

The diagnosis was made by showing a raised titre to measles in the cerebrospinal fluid in four of the patients and raised serum titres to measles in the other two. A postmortem examination on the child who died with raised titres only in the blood showed the typical inclusion bodies in the neurones. In case $6 \mathrm{a}$ brain biopsy gave negative results, but as the distribution of the lesions in the brain can be patchy negative findings can occur. As no other cause for the encephalopathy was found, and specifically no other virus was shown, and there was a definite history of close contact with measles the diagnosis of measles encephalitis based on raised serum titres alone was thought to be safe.

\section{PNEUMONIA}

A more common complication is severe pneumonia occurring at the time of the acute measles infection and 12 cases were found in this series, 10 of them fatal. Six of the 12 patients were given immunoglobulin, including one of the two survivors (table III). The pattern of the disease in the immuno-

TABLE II-Cases of measles encephalitis

\begin{tabular}{|c|c|c|c|c|c|c|c|}
\hline $\begin{array}{r}\text { Case } \\
\text { No }\end{array}$ & $\begin{array}{l}\text { Length of } \\
\text { continuous } \\
\text { complete } \\
\text { remission at } \\
\text { onset of } \\
\text { encephalitis }\end{array}$ & $\begin{array}{l}\text { Contact and } \\
\text { immunoglobulin } \\
\text { treatment }\end{array}$ & Incubation & Clinical course of measles & $\begin{array}{l}\text { Delay in onset of } \\
\text { encephalitis }\end{array}$ & $\begin{array}{l}\text { Symptoms of encephalitis, } \\
\text { treatment, and outcome }\end{array}$ & Virology and histology \\
\hline 1 & 10 Months & $\begin{array}{l}\text { Sibling, immunoglobulin not } \\
\text { given }\end{array}$ & Two weeks & $\begin{array}{l}\text { Fever, upper respiratory tract } \\
\text { infection, anorexia, Koplik's } \\
\text { spots, typical rash }\end{array}$ & Seven months & $\begin{array}{l}\text { Status epilepticus. Died three } \\
\text { weeks after onset of symptoms }\end{array}$ & $\begin{array}{l}\text { Cerebrospinal fluid measles } \\
\text { titre 80. No necropsy }\end{array}$ \\
\hline 2 & Five months & $\begin{array}{l}\text { Sibling, immunoglobulin not } \\
\text { given }\end{array}$ & Not known & No clinical measles & Four months & $\begin{array}{l}\text { Left sided hemiparesis, } \\
\text { generalised convulsions. } \\
\text { Intermittent positive pressure } \\
\text { ventilation for three months. } \\
\text { Died }\end{array}$ & $\begin{array}{l}\text { Cerebrospinal fluid measles } \\
\text { titre } 10 \text {. Necropsy showed } \\
\text { subacute viral encephalitis }\end{array}$ \\
\hline 3 & Seven months & $\begin{array}{l}\text { No specific contact, given } \\
\text { immunoglobulin twice because } \\
\text { of "prevalence of measles" }\end{array}$ & Not known & Atypical rash (possibly measles) & $\begin{array}{l}\text { Seven months } \\
\text { from rash }\end{array}$ & $\begin{array}{l}\text { Frequent generalised convulsions. } \\
\text { Died two weeks after onset of } \\
\text { symptoms }\end{array}$ & $\begin{array}{l}\text { Blood serology } 1 / 64 \text {. } \\
\text { Histology at necropsy } \\
\text { showed numerous inclusion } \\
\text { bodies in neurones and } \\
\text { astrocytes }\end{array}$ \\
\hline 4 & 14 Months & No known contact & Not known & $\begin{array}{l}\text { Upper respiratory tract infection, } \\
\text { Koplik's spots, atypical rash }\end{array}$ & 18 Weeks & $\begin{array}{l}\text { Frequent generalised convulsions. } \\
\text { On intermittent positive } \\
\text { pressure ventilation. Comatose } \\
\text { for three months. Cardiac arrest } \\
\text { and died }\end{array}$ & $\begin{array}{l}\text { Cerebrospinal fluid measles } \\
\text { titre } 32 \text {. No necropsy }\end{array}$ \\
\hline 5 & Two years & No known contact & Not known & $\begin{array}{l}\text { Upper respiratory tract infection, } \\
\text { mild atypical rash }\end{array}$ & $\begin{array}{l}\text { Three months } \\
\text { from rash }\end{array}$ & $\begin{array}{l}\text { Cortical blindness, three short } \\
\text { focal seizures. Intramuscular } \\
\text { and intrathecal interferon. Died } \\
\text { two months after onset of } \\
\text { symptoms }\end{array}$ & $\begin{array}{l}\text { High serum and cerebrospinal } \\
\text { fluid titres to measles }\end{array}$ \\
\hline 6 & Two years & $\begin{array}{l}\text { Close contact a few weeks before } \\
\text { encephalitis, immunoglobulin } \\
\text { not given }\end{array}$ & Not known & No clinical measles & $\begin{array}{l}\text { Few weeks from } \\
\text { only known } \\
\text { contact }\end{array}$ & $\begin{array}{l}\text { Left sided hemiparesis and right } \\
\text { sided convulsions. Acyclovir for } \\
10 \text { days. Alive but severely } \\
\text { handicapped }\end{array}$ & High serum titres \\
\hline
\end{tabular}


suppressed was that of a true measles pneumonitis rather than a secondary bacterial pneumonia as seen in the non-immunosuppressed, and antibiotics seemed to have little effect. In all of these patients both lungs were equally affected with progressive difficulty in ventilation due to "stiff lung" causing progressive hypoxia despite the use of increasing concentrations of oxygen, and cardiac arrest usually occurred as the terminal event within two to three weeks. Chest $x$ ray films showed extensive bilateral consolidation with air bronchograms and three patients had pneumomediastinum, but appearances on $x$ ray film were not specific for measles pneumonitis.

The diagnosis was made by showing the presence of measles antigen by

\section{Discussion}

It is a great tragedy that the 15 children who died had endured many months of investigation and treatment and were potentially cured of a malignant disease only to succumb to a "simple" and almost entirely preventable infection; the child who survived the encephalitis but was severely handicapped is unlikely to have a relapse of her leukaemia.

In our experience the effect of the measles virus on the immuno-

TABLE III-Cases of measles pneumonia

\begin{tabular}{|c|c|c|c|c|c|c|c|}
\hline $\begin{array}{l}\text { Case } \\
\text { No }\end{array}$ & $\begin{array}{l}\text { Length of } \\
\text { continuous } \\
\text { complete } \\
\text { remission }\end{array}$ & $\begin{array}{l}\text { Contact and } \\
\text { immunoglobulin } \\
\text { treatment }\end{array}$ & Incubation & Prodromal symptoms & $\begin{array}{l}\text { Clinical course of measles } \\
\text { and outcome }\end{array}$ & Treatment & Virology and histology \\
\hline 1 & Eight months & $\begin{array}{l}\text { Immediate (contact on } \\
\text { ward) }\end{array}$ & 18 Days & $\begin{array}{l}\text { Fever, upper respiratory tract } \\
\text { infection, anorexia, atypical } \\
\text { rash }\end{array}$ & $\begin{array}{l}\text { Severe pneumonia with } \\
\text { emphysema and } \\
\text { pneumomediastinum. Died }\end{array}$ & $\begin{array}{l}\text { Ribavirin by inhalation and } \\
\text { orally, antibiotics. } \\
\text { Ventilated }\end{array}$ & $\begin{array}{l}\text { Measles antigen identified } \\
\text { from throat swab. } \\
\text { No necropsy }\end{array}$ \\
\hline 2 & 18 Months & $\begin{array}{l}\text { No history of contact. } \\
\text { Immunoglobulin not } \\
\text { given }\end{array}$ & Not known & Upper respiratory tract infection & $\begin{array}{l}\text { Bilateral pneumonia, cardiac } \\
\text { arrest after lung aspiration. } \\
\text { Died }\end{array}$ & Intravenous antibiotics & $\begin{array}{l}\text { Viral cultures negative. } \\
\text { Necropsy showed } \\
\text { multinucleated giant cells in } \\
\text { alveoli }\end{array}$ \\
\hline 3 & 22 Months & $\begin{array}{l}\text { No history of contact. } \\
\text { Immunoglobulin not } \\
\text { given }\end{array}$ & Not known & $\begin{array}{l}\text { Fever, upper respiratory tract } \\
\text { infection }\end{array}$ & $\begin{array}{l}\text { Bilateral pneumonia } \\
\text { unresponsive to treatment. } \\
\text { Died }\end{array}$ & Interferon & $\begin{array}{l}\text { Measles antigen identified } \\
\text { from nasopharyngeal } \\
\text { aspirate. Necropsy showed } \\
\text { multinucleated giant cells in } \\
\text { alveoli }\end{array}$ \\
\hline 4 & Two years & $\begin{array}{l}\text { Immunoglobulin given } \\
\text { four days after contact }\end{array}$ & Two weeks & $\begin{array}{l}\text { Fever, upper respiratory tract } \\
\text { infection, atypical rash }\end{array}$ & $\begin{array}{l}\text { Bilateral pneumonia. } \\
\text { Recovered }\end{array}$ & Interferon for one week & $\begin{array}{l}\text { Measles antigen identified } \\
\text { from nasopharyngeal } \\
\text { aspirate. No necropsy }\end{array}$ \\
\hline 5 & Six months & $\begin{array}{l}\text { Immunoglobulin not } \\
\text { given. Sister had } \\
\text { measles two months } \\
\text { before patient's } \\
\text { symptoms }\end{array}$ & $\begin{array}{l}\text { Possibly two } \\
\text { months }\end{array}$ & $\begin{array}{l}\text { Fever, upper respiratory tract } \\
\text { infection }\end{array}$ & $\begin{array}{l}\text { Bilateral pneumonia with } \\
\text { emphysema in } \\
\text { mediastinum, neck, and } \\
\text { thoracic wall. Died }\end{array}$ & Interferon & $\begin{array}{l}\text { Measles antigen and } \\
\text { multinucleated giant cells } \\
\text { found in nasopharyngeal } \\
\text { aspirate. No necropsy }\end{array}$ \\
\hline 6 & Three months & $\begin{array}{l}\text { Immunoglobulin not } \\
\text { given. No contact }\end{array}$ & Not known & $\begin{array}{l}\text { Fever, upper respiratory tract } \\
\text { infection, atypical rash }\end{array}$ & $\begin{array}{l}\text { Progressive pneumonia. } \\
\text { Died }\end{array}$ & Ventilated & $\begin{array}{l}\text { Measles antigen identified } \\
\text { from nasopharyngeal } \\
\text { aspirate. Serology showed } \\
\text { increased measles titres. } \\
\text { Histology at necropsy } \\
\text { showed giant cell } \\
\text { pneumonia }\end{array}$ \\
\hline 7 & Eight months & $\begin{array}{l}\text { Immunoglobulin given } \\
\text { one day after contact }\end{array}$ & 11 Days & $\begin{array}{l}\text { Fever, upper respiratory tract } \\
\text { infection }\end{array}$ & $\begin{array}{l}\text { Progressive bilateral } \\
\text { pneumonia. Died }\end{array}$ & Interferon & $\begin{array}{l}\text { Measles virus found in } \\
\text { nasopharyngeal aspirate. } \\
\text { Histology at necropsy } \\
\text { showed multinucleated } \\
\text { giant cell pneumonia }\end{array}$ \\
\hline 8 & Six months & No history of contact & Not known & $\begin{array}{l}\text { Fever, upper respiratory tract } \\
\text { infection, anorexia, atypical } \\
\text { rash }\end{array}$ & $\begin{array}{l}\text { Progressive bilateral } \\
\text { pneumonia. Died }\end{array}$ & Antibiotics & $\begin{array}{l}\text { Measles antigen identified } \\
\text { from nasopharyngeal } \\
\text { aspirate. No necropsy }\end{array}$ \\
\hline 9 & Six months & No history of contact & Not known & $\begin{array}{l}\text { Fever, upper respiratory tract } \\
\text { infection }\end{array}$ & Bilateral pneumonia. Died & Antibiotics & $\begin{array}{l}\text { Histology at necropsy showed } \\
\text { giant cell pneumonia }\end{array}$ \\
\hline 10 & Nine months & No history of contact & Not known & $\begin{array}{l}\text { Fever, upper respiratory tract } \\
\text { infection, atypical rash }\end{array}$ & $\begin{array}{l}\text { Progressive pneumonitis. } \\
\text { Died }\end{array}$ & $\begin{array}{l}\text { Antibiotics, acyclovir. } \\
\text { Ventilated }\end{array}$ & $\begin{array}{l}\text { Giant cell pneumonitis found } \\
\text { on lung biopsy. Necropsy } \\
\text { showed measles } \\
\text { pneumonitis }\end{array}$ \\
\hline 11 & Six months & $\begin{array}{l}\text { Immunoglobulin given } \\
\text { immediately after } \\
\text { contact with sibling }\end{array}$ & Six weeks & $\begin{array}{l}\text { Fever, upper respiratory tract } \\
\text { infection, vomiting, atypical } \\
\text { rash }\end{array}$ & $\begin{array}{l}\text { Extensive bilateral } \\
\text { consolidation. Died }\end{array}$ & Antibiotics. Ventilated & $\begin{array}{l}\text { Lung biopsy showed } \\
\text { multinucleated giant cells. } \\
\text { No necropsy }\end{array}$ \\
\hline 12 & 14 Months & $\begin{array}{l}\text { No history of contact. } \\
\text { Immunoglobulin not } \\
\text { given }\end{array}$ & Not known & $\begin{array}{l}\text { Fever, upper respiratory tract } \\
\text { infection, anorexia, atypical } \\
\text { rash }\end{array}$ & $\begin{array}{l}\text { Bilateral lower lobe } \\
\text { pneumonia two months } \\
\text { after rise in measles titres. } \\
\text { Recovered }\end{array}$ & Antibiotics & High serum titres \\
\hline
\end{tabular}

immunofluorescence from nasopharyngeal aspirate in six cases and from a throat swab in one case. In two cases lung biopsy showed the typical multinucleated giant cell pneumonitis, and in another two cases the suspected diagnosis was confirmed at necropsy by finding multinucleated giant cells. The 12th case differed from the others in that the severe pneumonia occurred two months after the rise in measles titres, although the child was unwell throughout the intervening time, and a bronchoscopy failed to find a causative organism. The patient improved symptomatically after the bronchoscopy without any specific antiviral treatment but later suffered repeated chest infections. The other child who recovered was treated with interferon for a week but, as four of the children who died were given similar treatment, it is difficult to give a particular reason for his survival. One of the children who died was treated with ribavirin and one with acyclovir, without success. There was no standard regimen in use for treating this severe infection at the time these cases occurred, and in general both the patients with encephalitis and those with pneumonitis were treated symptomatically, with the more recent cases being given the new antiviral agents but not on the basis of a controlled trial. The types of interferon used and the doses and the routes of administration are not tabulated because this information was not always available. compromised patient is devastating and the normal symptoms of measles are rarely present. The experience of the Newcastle group (see paper at p 15) was less severe, although the mortality in that series was still $29 \%(5 / 17)$ compared with our figure of $83 \cdot 3 \%$ $(15 / 18)$. The reason for the difference probably lies with the availability in Newcastle for many years of a rapid virological diagnosis; this may have identified mild cases of measles that were not picked up at the four centres in this study.

The phenomenon of the abnormal clinical picture of measles infection that presumably occurs because of the altered immunity of the patient can make initial diagnosis difficult, and a high index of suspicion of the possibility of measles must be maintained in those treating immunocompromised patients especially in cases of encephalitis, where there may be a delay of up to seven months from exposure to the virus. These complications were first described some years ago, but no effective treatment regimen has yet been found. ${ }^{7 \cdot 11}$

The answer to the problem seems to lie in prevention by 
drastically improving the uptake of measles vaccination in the community and by finding more effective prophylaxis for those immunocompromised patients known to have been exposed to the measles virus. If the vaccine uptake in the general population were to be increased to over $90 \%$ as it is in the United States of America, ${ }^{1213}$ as opposed to $50-60 \%$ as in some parts of the United Kingdom, ${ }^{14}$ the herd immunity would be much improved and the risk of contact for those still susceptible would be greatly reduced. Children who are immunocompromised during the period of treatment (which can last up to three years) and for several months thereafter are encouraged to lead as normal a life as possible including attendance at school, though parents and teachers are warned about avoiding contact with infectious diseases. Several recent reports ${ }^{15.17}$ have shown that a major effort by the primary health care and community medicine teams can increase immunisation uptake enormously with subsequent benefit for the community (measles can still cause mortality and morbidity in otherwise healthy children $)^{1819}$ as well as for special groups like immunocompromised patients. Even if the problem of the partial failure of the immunisation programme could be overcome, however, effective prophylaxis would still be needed and a trial of a new high dose intravenous hyperimmune globulin which has been produced by the Scottish National Blood Transfusion Service is being undertaken at the four centres which participated in this study and at the Royal Victoria Infirmary, Newcastle. It is proposed to investigate the use of a newer high dose interferon, possibly in conjunction with the high dose intravenous immunoglobulin, as treatment in complicated cases.

We thank Dr Judith Chessells of the Hospital for Sick Children, Great
Ormond Street, London, for permitting us to include her patients and Mrs Mary McAllister and Mrs Maureen Marshall for secretarial work.

\section{References}

1 Mauer AM. New directions in the treatment of acute lymphoblastic leukaemia in children. $N$ Engl

$\mathcal{F}$ Med 1986;315:316-7.
2 Hughes TW, Kuhn S, Chaudhary S, et al. Successful prophylaxis for Pneumocystis carinii Hughes TW, Kuhn S, Chaudhary S, et al. Suce
pneumonia. N Englf Med 1977;297:1419-26.

3 Hann IM, Prentice HG, Blacklock HA, et al. Acyclovir prophylaxis against herpes virus infections in severely immunocompromised patients: randomised double blind trial. Br Med $\mathcal{F}$ 1983;287: 384-8.

4 Mitus A, Holloway A, Evans AE, Enders JF. Attenuated measles vaccine in children with acute leukaemia. Am $\mathcal{F}$ Dis Child 1962;103:413-8.

5 Torigoe $\mathrm{S}$, Hirai $\mathrm{S}$, Oitani $\mathrm{K}$, et al. Application of live attenuated measles and mumps vaccines in children with acute leukaemia. Biken $1981 ; 24: 147-51$.

6 Kay HEM, Rankin A. Immunoglobulin prophylaxis of measles in acute lymphoblastic leukaemia. Lancet 1984;i:901-2.

7 Pullan CR, Noble TC, Scott DJ, Wisniewski K, Gardner PS. Atypical measles infections in children on immunosuppressive treatment. Br Med $\mathcal{J}$ 1976;i:1562-5.

8 Mitus A, Enders JF, Craig JM, Holloway A. Persistence of measles virus and depression of antibody formation in patients with giant cell pneumonia after measles. N Engl $\mathcal{J}$ Med 1959;261:882-9.

9 Jones HE. Immunosuppression and fatal measles. Lancet 1969;ii:1255-6.

10 Anonymous. Measles encephalitis during immunosuppressive treatment. [Editorial.] $\mathrm{Br} \mathrm{Med} \mathrm{F}$ 1976;i: 1552 .

11 Simpson R, Eden OB. Possible interferon response in a child with measles encephalitis during immunosuppression. Scand $\mathcal{Y}$ Infect Dis 1984;16:315-9.

12 Hinman AR, Eddins DL, Kirby CD, et al. Progress in measles elimination. JAMA 1982;247: 1592-5.

13 Katz S. Measles-forgotten but not gone. N Engl f Med 1985;313:577-8.

14 Campbell AGM. Measles immunisation: why have we failed? Arch Dis Child 1983;58:3-5.

15 Ross SK. Childhood immunoprophylaxis: achievements in a Glasgow practice. Edinburgh: Scottish Home and Health Department, 1983:253-7. (Bulletin issued by chief medical officer, 41/5.)

16 Fernandes V, Gill ON. Prevention of measles: vaccine efficacy and potential effectiveness of a vaccination programme on entry to school. Br Med $\mathcal{F} 1985 ; 291: 1685$.

17 Anderson P. Measles immunisation. Br Med f 1985;291:1616.

17 Anderson P. Measles immunisation. Br Med F 1985;291:1616.
18 Miller CL. Deaths from measles. in England and Wales, 1970-83. Br Med J 1985;290:443-4.

19 Walker $\mathrm{E}$. Reasons for admission to hospital and complications in children with measles. Edinburgh: Scottish Home and Health Department, 1983:300-4. (Bulletin issued by chief medical officer, 41/6.)

(Accepted 24 April 1987)

\title{
Live measles vaccine: a 21 year follow up
}

\author{
CHRISTINE MILLER
}

\begin{abstract}
21 years after receiving Schwarz strain live measles vaccine 4500 trial participants showed a continuing high level of protection compared with those who were unvaccinated. Over the last seven years of the follow up no cases of measles were reported in vaccinated participants who had had close contact with the disease.

Immunity induced by the vaccine seems to survive the challenge of close contact with measles in young children, even after 21 years.
\end{abstract}

\section{Introduction}

In September 1964 a Medical Research Council trial began in England and Wales to assess the immediate anu long term protection afforded by measles vaccines. Over 36000 children aged between 10 months and 2 years were randomly allocated either to receive live,

\footnotetext{
Public Health Laboratory Service Communicable Disease Surveillance Centre, Colindale, London NW9

CHRISTINE MILLER, BM, MFCM, senior epidemiologist
}

further attenuated measles vaccine alone (9538 children) or four weeks after an injection of killed vaccine (10434) or to remain unvaccinated (16239). Those who had a history of measles were excluded from the trial. Both vaccinated and unvaccinated children (including those ineligible because of illness and those who defaulted from vaccination) were followed up by a nurse at three, six, and nine months to assess clinical reactions to the vaccine and :establish the incidence of measles in each group.

Four previous reports have been published. The first described the design of the trial and covered the initial six months of the follow up.' The second and third reports gave the results at two years nine months ${ }^{2}$ and four years nine months, ${ }^{3}$ respectively, and the fourth reported 12 years after vaccination. ${ }^{4}$ The present report gives the results for a further nine years up to September 1985, 21 years after vaccination.

\section{Subjects and methods}

As previously stated, ${ }^{23}$ the number of participants in the trial was reduced after the first nine months. Over 2000 children from each of the three vaccine groups were lost to follow up when five of the participating local authority areas withdrew from the trial to take part in a community investigation. ${ }^{5}$ In addition, because of an undertaking given at the outset of the trial, vaccination was offered to the control group after the first nine months; 7000 children were vaccinated and were therefore lost to follow up as controls. 